\title{
Analysis of insecticides in okra and brinjal from IPM and non-IPM fields
}

\author{
Sumitra Arora
}

Received: 27 September 2007 / Accepted: 3 March 2008 / Published online: 16 April 2008

(C) Springer Science + Business Media B.V. 2008

\begin{abstract}
Samples of okra and brinjal fruits, collected from non-integrated pest management (Non-IPM) and IPM fields in village Raispur, Ghaziabad District (U.P.), were analyzed for pesticide residues. The residues of chlorpyrifos in soil were 4.219 and $1.135 \mu \mathrm{g} / \mathrm{g}$ at harvest time in non-IPM and IPM fields of summer okra crop from initial value of $0.407 \mu \mathrm{g} / \mathrm{g}$ before sowing, while in brinjal crop, it was not detected in soils of any trials. During first year of study, the residues of chlorpyrifos and cypermethrin in okra fruit were observed to be 5.75 and $0.625 \mu \mathrm{g} / \mathrm{g}$, respectively, for non-IPM fields; and $0.104 \mu \mathrm{g} / \mathrm{g}$ of chlorpyrifos for IPM trials. The pesticide residues were found to be $0.77,1.39,0.4$ and $0.32 \mu \mathrm{g} / \mathrm{g}$ for cypermethrin, chlorpyrifos, monocrotophos and dimethoate, respectively, for non-IPM okra fruits in second year. For brinjal fruit, residues of cypermethrin and imidacloprid were not detected in IPM trials while it was found to be 0.28 and $0.78 \mu \mathrm{g} / \mathrm{g}$ for cypermethrin and chlorpyrifos respectively, for non-IPM trials.
\end{abstract}

Keywords Cypermethrin - Chlorpyrifos · Monocrotophos · Dimethoate $\cdot$ Imidacloprid . Residues $\cdot$ Okra $\cdot$ Brinjal

S. Arora $(\bowtie)$

National Centre for Integrated Pest Management, Lal Bahadur Shashtri Building, Pusa Campus,

New Delhi 110 012, India

e-mail: sumitraarora@hotmail.com

\section{Introduction}

Okra (Abelmoschus esculentus L. Moench) and brinjal (Solenum melongena L.) crops are extensively grown vegetables all over the country. Both the crops are attacked by multitude of insect pests and diseases. The pests are documented for both okra (Adiroubane and Letchoumanane 1998) and brinjal (Sardana et al. 2004). $13-14 \%$ of total pesticides used in the country are applied in vegetable crops. Since the produce is harvested at short intervals and consumed fresh in many cases, the surveys of market samples show high level of pesticide residues (Arora and Gopal 2002 Agnihotri 1999; Awasthi and Ahuja 1997) in vegetables. Thus for reducing the pesticide load, Integrated Pest Management (IPM) strategies involving need based application of pesticides have been developed for vegetable crops especially okra and brinjal.

\section{Experimental}

Okra (YVM resistant hybrids Sun-40 \& Makhmali) and brinjal (Hybrid F1-321) crop trials were laid at farmer's field at village Raispur, District Ghaziabad Uttar Pradesh, India during 2003-2004 in a randomized block design consisting of five treatments (modules) with four replications each. The brinjal crop was sown in the first week of July in nursery and transplanted in field with inter and intra row spacing 
of $75 \times 45 \mathrm{~cm}^{2}$ in the first week of August. Similarly okra crop was sown in the first week of March in nursery and transplanted in field in the first week of April. The row to row and plant to plant distance of $60 \times 30 \mathrm{~cm}^{2}$ was maintained for okra as per the recommended agronomical practices of that area.

In kharif okra, leaf hopper, Amrasca bigutulla bigutulla Ishida; white fly, Bemicia tabaci Gennadius and mites were observed as the major sucking pests and shoot and fruit borer, Earias vitella Fabricius as the major borer pest. Among diseases, heavy infection of yellow vein mosaic virus was observed in non-IPM fields. Negligible infection of powdery mildew and red cotton bug infestation was seen at the late stage. Brinjal crop during its different growth stages is attacked by a number of insect pests and diseases viz; aphids, Aphis gossypii Glover; leaf hopper, A. bigutulla bigutulla Ishida; hadda beetle, Epilachna dodecastigma Mulsant and Epilachna vigintioctopunctata Fabricius, leaf folder, Eublemma olivacea (Walker) and shoot \& fruit borer, Leucinodes orbonalis Guenee; little leaf, Sclerotinia sclerotiorum and Phomopsis vexan. But Leaf hopper, shoot and fruit borer were of main concern.

The average relative humidity and sunshine hour was 55.3 and $5.2 \mathrm{~h}$, respectively. The average wind speed was $2.18 \mathrm{~km} / \mathrm{h}$ and there was no rainfall during the studies. The maximum and minimum average temperatures were $27.8^{\circ} \mathrm{C}$ and $16.2^{\circ} \mathrm{C}$, respectively.

\section{Field experiments}

\section{Non-IPM trials (Farmers practice)}

In brinjal crop, monocrotophos (36 SL) at $0.05 \%$ ( $0.75 \mathrm{~L} /$ ha as spray volume) was repeatedly sprayed for the management of hoppers and shoot and fruit borers. Megha, a mixture of chlorpyrifos 50\% EC and cypermethrin $5 \% \mathrm{EC}$, at $5 \mathrm{ml} / \mathrm{L}$, was used repeatedly by farmers for the management of leafhoppers, whitefly and shoot and fruit borer during the first year (2003-2004) trials with okra crop. During second year 2004-2005, the farmers applied first spray of monocrotophos at $0.05 \%$ followed by deltamethrin $(2.8 \mathrm{EC}$ at $1 \mathrm{ml} / \mathrm{L})$ and dimethoate (30 EC at $3 \mathrm{ml} / \mathrm{L}$ ). Then Megha at $5 \mathrm{ml} / \mathrm{L}$ was sprayed followed by a mixture of cypermethrin, chlorpyrifos, monocrotophos and dimethoate insecticides at $5 \mathrm{ml} / \mathrm{L}$ as second spray. These insecticides were sprayed at the interval of 15 days. A single spray of cypermthrin $5 \% \mathrm{EC}$ at $1 \mathrm{ml} / \mathrm{L}$ was given followed by imidacloprid $17.8 \mathrm{SL}$ at $0.01 \%$ in brinjal crop. For brinjal crop megha was applied at $5 \mathrm{ml} / \mathrm{L}$ on 120 days after transplanting.

\section{IPM trials}

For IPM trials single spray of cypermethrin (at $5 \mathrm{ml} / \mathrm{L}$, 60 days after transplanting for brinjal and 45 days after sowing for okra) and imidacloprid (at $0.01 \%, 85$ days after transplanting for brinjal and 60 days after sowing for okra) were given to each of okra and brinjal crop. For control of sucking pests in brinjal crop, imidacloprid $17.8 \mathrm{SL}$ at $0.01 \%$ was used in IPM as well as non-IPM trials.

Analysis of pesticide residues

For recovery studies, cypermethrin, chlorpyrifos, monocrotophos, dimethoate and imidacloprid, were spiked at two fortification levels i.e. 0.1 and $1.0 \mu \mathrm{g} / \mathrm{g}$ in the control samples (with no chemical treatment) of okra and brinjal fruits. The method giving highest recovery was used for residue analysis of soil and vegetable fruits samples.

Marketable representative samples of okra and brinjal fruits were drawn randomly from three replicates of IPM and non-IPM trials. A sub sample each of $50 \mathrm{~g}$ was drawn from each replicate. The samples were chopped and homogenized separately with $100 \mathrm{ml}$ acetone. Okra fruit samples were analyzed as per Kole et al. (2002) method with slight modification i.e. $5 \mathrm{~g}$ neutral alumina (activated at $110^{\circ} \mathrm{C}$ ), sandwiched between two layers of anhydrous sodium sulphate was used as adsorbent and n-hexane as eluting solvent for clean up. Brinjal fruits samples were analyzed as per the method reported by Madan et al. (1996) with modifications. Five grams of silica gel (activated) packed between two layers of anhydrous sodium sulphate in a glass column was used as adsorbent for clean up of monocrotophos residues in brinjal and it was eluted with mixture of hexane/acetone (80:20).

Before sowing and after harvesting of okra and brinjal crops, the representative soil samples $(15 \mathrm{~cm}$ depth) including control, were collected in triplicate from each replicate of IPM and non-IPM fields with an auger tube for analysis of chlorpyrifos. The soil samples were dried under shade by spreading them overnight on a paper. After sieving the soil through a 
Table 1 Soil residues of chlorpyrifos during 2003-2004

\begin{tabular}{llll}
\hline Crop & Sampling time & \multicolumn{2}{l}{ Residues $(\mu \mathrm{g} / \mathrm{g})$} \\
\cline { 3 - 4 } & & IPM & $\begin{array}{l}\text { Non-IPM } \\
\text { (farmers practice) }\end{array}$ \\
\hline Okra & Before sowing & $0.40-0.407$ & $0.40-0.407$ \\
& After sowing & $1.12-1.135$ & $3.89-4.219$ \\
Brinjal & Before sowing & $<0.01$ & $<0.01$ \\
& After sowing & $<0.01$ & $<0.01$ \\
\hline
\end{tabular}

$2 \mathrm{~mm}$ mesh sieve, a sub sample of $20 \mathrm{~g}$ was drawn by quartering method, in a $250 \mathrm{ml}$ conical flask. For residue analysis of insecticide in soil, shaking method (Arora and Gopal 2004) was used for simultaneous one step extraction and cleanup using activated neutral alumina as adsorbent. It was then eluted with $100 \mathrm{ml}$ hexane/acetone $(1: 1, v / v)$ solvent system for chlorpyrifos. The eluents were rotary evaporated and volume was made up to $10 \mathrm{ml}$ with freshly distilled hexane. It was then subjected to analysis using GLC fitted with an electron capture detector (ECD). The method giving highest recovery was used for residue analysis of samples.

The fruit samples of okra and brinjal were analyzed for the insecticides viz. chlorpyrifos, cypermethrin, deltamethrin, dimethoate, monocrotophos and imidacloprid sprayed in that area. The method of analysis was optimized for residues analysis of all pesticides and the recoveries were found to be more than $80 \%$. Residues of all the insecticides except imidacloprid were estimated by GLC (HP 5890 series II) equipped with mega bore column (HP-1, $25 \mathrm{~m}, 0.53 \mathrm{~mm}$ id with film thickness $2.65 \mu \mathrm{m}$ film thickness) and ECD detector.

The operating parameters were: Detector $280^{\circ} \mathrm{C}$; Injector $250^{\circ} \mathrm{C}$; Column $170^{\circ} \mathrm{C}$ maintained for $10 \mathrm{~min}$, then raised@25 $25^{\circ} \mathrm{min}^{-1}$ to $240^{\circ} \mathrm{C}$ and held for $15 \mathrm{~min}$; flow rate of $\mathrm{N}_{2}$ gas was $15 \mathrm{ml} \mathrm{min}^{-1}$. The retention time (Rt) of chlorpyrifos and cypermethrin were 8.65 and $19.64 \mathrm{~min}$, respectively. For monocrotophos, deltamethrin and dimethoate, Rt was observed to be $3.72,23.4$ and $3.41 \mathrm{~min}$, respectively. The detection of insecticides was confirmed by Gas chromatography-mass spectrometry. The limit of detection for cypermethrin, deltamethrin and chlorpyrifos, was $0.01 \mu \mathrm{g} / \mathrm{g}$; for monocrotophos and dimethoate $0.3 \mu \mathrm{g} / \mathrm{g}$, and for imidacloprid it was $0.05 \mu \mathrm{g} / \mathrm{g}$. For imidacloprid estimation, High performance liquid chromatography (Merck \& Lachrom) equipped with RP-8 column and ultraviolet detector was used. The solvent system was acetonitrile/water $(60: 40, v / v)$ at flow rate of $1 \mathrm{ml} / \mathrm{min}$ at $\lambda_{\max }=270 \mathrm{~nm}$. The retention time (Rt) for imidacloprid was $5.23 \mathrm{~min}$.

\section{Results and discussions}

Soil samples collected from okra fields, before sowing, showed the presence of chlorpyrifos up to $0.407 \mu \mathrm{g} / \mathrm{g}$ (see Table 1), which might have been sprayed in the previous year in okra/other vegetable crops (Arora and Singh 2004), thereby indicating persistent nature of this insecticide. Due to repeated sprays of Megha pesticide mixture by non-IPM farmers, the soil samples collected from okra field after harvesting of the crop indicated increase in amount of chlorpyrifos to a level of $4.219 \mu \mathrm{g} / \mathrm{g}$ from an initial amount of $0.407 \mu \mathrm{g} / \mathrm{g}$. The residues of chlorpyrifos in soil increased to a moderate level of $1.135 \mu \mathrm{g} / \mathrm{g}$ in IPM field, wherein very less pesticide was used. The soil samples collected from the brinjal fields before the initiation of trial did not show presence of any residues of chlorpyrifos. This may

Table 2 Residues of insecticides in okra and brinjal fruits at harvest during 2003-2004

\begin{tabular}{|c|c|c|c|c|c|c|c|c|c|}
\hline \multirow[t]{3}{*}{ Crop } & \multirow[t]{3}{*}{ Trial } & \multicolumn{8}{|c|}{ Residues ( $\mu \mathrm{g} / \mathrm{g})$} \\
\hline & & \multicolumn{4}{|l|}{ IPM } & \multicolumn{4}{|c|}{ Non-IPM (farmers practices) } \\
\hline & & $\mathrm{R}_{1}$ & $\mathrm{R}_{2}$ & $\mathrm{R}_{3}$ & Mean & $\mathrm{R}_{1}$ & $\mathrm{R}_{2}$ & $\mathrm{R}_{3}$ & Mean \\
\hline \multirow[t]{2}{*}{ Okra } & Chlorpyrifos & 0.098 & 0.107 & 0.106 & $0.10(0.2)^{*}$ & 5.80 & 5.72 & 5.74 & $5.75(0.2)$ \\
\hline & Cypermethrin & ND & ND & ND & $\mathrm{ND}(0.2)$ & 0.621 & 0.628 & 0.625 & $0.63(0.2)$ \\
\hline Brinjal & Monocrotophos & ND & ND & ND & $\mathrm{ND}(0.2)$ & 1.20 & 1.26 & 1.30 & $1.25(0.2)$ \\
\hline
\end{tabular}

MRL of respective pesticide is given in parentheses

$N D$ Not detected 
be due to the fact that the brinjal field was kept fallow for a long period before taking up the trial, which might have resulted in the degradation of chlorpyrifos insecticide in soil.

For pesticide residue analysis sampling of okra fruit was not feasible at each harvest as these were harvested every alternate day. Therefore when the samples of okra and brinjal fruits were collected from IPM trials on first, 15th, 20th /25th day of spraying, fruits from non-IPM trials were also collected for comparative study of pesticide residues. During the first year (2003-2004) monitoring of cypermethrin and chlorpyrifos was studied in okra, while for brinjal crop monocrotophos was selected for monitoring studies. The results in Table 2 revealed residues of chlorpyrifos and cypermethrin in okra fruits as $0.104 \mu \mathrm{g} / \mathrm{g}$ and ND for IPM trials and 5.75 and $0.63 \mu \mathrm{g} / \mathrm{g}$ for non-IPM fields, respectively. The

Table 3 Residues of insecticides in okra and brinjal fruits at harvest during 2004-2005

\begin{tabular}{|c|c|c|c|c|c|}
\hline \multirow[t]{2}{*}{ Crop } & \multirow[t]{2}{*}{ Pesticides } & & \multirow[t]{2}{*}{ Sampling (DAA) } & \multicolumn{2}{|c|}{ Residues $(\mu \mathrm{g} / \mathrm{g})$} \\
\hline & & & & IPM & Non-IPM \\
\hline \multirow[t]{28}{*}{ Okra } & \multirow[t]{14}{*}{ Single spray } & \multirow[t]{3}{*}{ Cypermethrin (45 DAS) } & 01 & $0.53(0.2)^{*}$ & NS \\
\hline & & & 15 & 0.02 & NS \\
\hline & & & 20 & ND & NS \\
\hline & & \multirow[t]{2}{*}{ Imidacloprid (60 DAS) } & 01 & 4.8 & NS \\
\hline & & & 25 & ND & NS \\
\hline & & \multirow[t]{3}{*}{ Monocrotophos (75 DAS) } & 01 & $\mathrm{NS}(0.2)^{*}$ & 3.76 \\
\hline & & & 15 & NS & 0.05 \\
\hline & & & 20 & NS & ND \\
\hline & & \multirow[t]{3}{*}{ Deltamethrin (90 DAS) } & 01 & NS & 1.45 \\
\hline & & & 15 & NS & 0.12 \\
\hline & & & 20 & NS & 0.01 \\
\hline & & \multirow[t]{3}{*}{ Dimethoate (105 DAS) } & 01 & $\mathrm{NS}(2.0)^{*}$ & 3.59 \\
\hline & & & 15 & NS & 0.29 \\
\hline & & & 20 & NS & ND \\
\hline & \multirow{6}{*}{$\begin{array}{l}\text { Mixture of first spray- } \\
\text { Megha (120 DAS) }\end{array}$} & \multirow[t]{3}{*}{ Cypermethrin } & 01 & NS & 0.68 \\
\hline & & & 15 & NS & 0.28 \\
\hline & & & 20 & NS & 0.04 \\
\hline & & \multirow[t]{3}{*}{ Chlorpyrifos } & 01 & NS & 5.8 \\
\hline & & & 15 & NS & 1.13 \\
\hline & & & 20 & NS & 0.62 \\
\hline & \multirow{8}{*}{$\begin{array}{l}\text { Mixture of Second } \\
\text { spray (135 DAS) }\end{array}$} & \multirow[t]{2}{*}{ Cypermethrin } & 01 & NS & 1.8 \\
\hline & & & 15 & NS & 0.77 \\
\hline & & \multirow[t]{2}{*}{ Chlorpyrifos } & 01 & NS & 6.65 \\
\hline & & & 15 & NS & 1.39 \\
\hline & & \multirow[t]{2}{*}{ Monocrotophos } & 01 & NS & 4.79 \\
\hline & & & 15 & NS & 0.4 \\
\hline & & \multirow[t]{2}{*}{ Dimethoate } & 01 & NS & 4.65 \\
\hline & & & 15 & NS & 0.32 \\
\hline \multirow[t]{8}{*}{ Brinjal } & \multirow[t]{4}{*}{ Single spray } & \multirow[t]{2}{*}{ Cypermethrin (60 DAT) } & 01 & $0.72(0.2)^{*}$ & 1.74 \\
\hline & & & 20 & ND & 0.28 \\
\hline & & \multirow[t]{2}{*}{ Imidacloprid (85 DAT) } & 01 & 6.1 & 8.5 \\
\hline & & & $>25$ & ND & ND \\
\hline & \multirow{4}{*}{$\begin{array}{l}\text { Mixture of spray-Megha } \\
\text { (120 DAT) }\end{array}$} & \multirow[t]{2}{*}{ Cypermethrin } & 01 & NS & 1.16 \\
\hline & & & 20 & NS & 0.19 \\
\hline & & \multirow[t]{2}{*}{ Chlorpyrifos } & 01 & $\mathrm{NS}(0.2)^{*}$ & 6.76 \\
\hline & & & 20 & NS & 0.78 \\
\hline
\end{tabular}

MRL of respective pesticide is given in parentheses

$D A S$ Days after sowing, $D A A$ days after application, $D A T$ days after transplanting, $N D$ not detected, $N S$ not sprayed 
residues of monocrotophos in brinjal fruits were found to be ND $(\mu \mathrm{g} / \mathrm{g})$ for IPM and $1.25 \mu \mathrm{g} / \mathrm{g}$ for non-IPM trials, before their delivery to market.

For second year (2004-2005) monocrotophos, deltamethrin, cypermethrin, chlorpyrifos, dimethoate and imidacloprid, sprayed during the crop season, were monitored for study (see Table 3). The residues of monocrotophos, deltamethrin, dimethoate, imidacloprid and cypermethrin were either in traces or not detected for IPM as well as non-IPM okra crop after 15 or 20 days of spray. After second spray it was observed to be $0.77,1.39,0.4$ and $0.32 \mu \mathrm{g} / \mathrm{g}$ for cypermethrin, chlorpyrifos, monocrotophos and dimethoate, respectively, for non-IPM okra crop after 15 days of spray. For brinjal crop, residues of cypermethrin and imidacloprid were not detected in IPM trials while it was found to be 0.28 and $0.78 \mu \mathrm{g} / \mathrm{g}$ for cypermethrin and chlorpyrifos respectively, for non-IPM trials. The yield of okra fruit for IPM trials was $103.05 \mathrm{q} /$ ha while that for non-IPM it was $72.46 \mathrm{q} / \mathrm{ha}$. In case of brinjal, the yield for IPM trials was $613 \mathrm{q} / \mathrm{ha}$ and $509 \mathrm{q} / \mathrm{ha}$ for non-IPM trials.

\section{Conclusion}

From the results obtained it can be concluded that harvest produce from IPM trials were safe for consumption as the residues of insecticides were either below their MRL (Kole et al. 2002) or were not detectable. The residues of monocrotophos, dimethoate and chlorpyrifos in non-IPM trails of okra and brinjal crop were as high as 5.0 to $6.0 \mu \mathrm{g} / \mathrm{g}$ (Table 3) after 1 day of spray before delivery to market. This is very alarming situation for pesticide residues crossing a high level from their respective MRLs. A waiting period of at least 15-20 days has to be observed for vegetable crops before their delivery to market for human consumption. This is not feasible for these vegetables, which are harvested every alternate day. Moreover the use of highly hazardous insecticides like monocrotophos (class II recommended by World Health Organization) should be avoided in vegetable crops. In addition it was considered relevant to record our concern that the persistent insecticide like chlorpyrifos or mixtures having chlorpyrifos insecticide may affect the soil fauna and therefore should be avoided in vegetable crops for managing the pests.

\section{References}

Adiroubane, D., \& Letchoumanane, S. (1998). Field efficacy of botanical extracts for controlling major insect pests of okra (Abelmoschus esculentus). Indian Journal of Agricultural Sciences, 68, 168-170.

Agnihotri, N. P. (1999). Supervised trials of pesticides on crops. In N. P. Agnohotri (Ed.) Pesticide, Safety Evaluation and Monitoring (p. 71). New Delhi: AICRP on Pesticide Residues, Division of Agricultural Chemicals, I.A.R.I.

Awasthi, M. D., \& Ahuja, A. K. (1997). Occurrence of pesticide residues in market and farmgate samples of vegetables in and around Bangalore city. Journal of Food Science and Technology - Mysore, 34, 146.

Arora, S., \& Gopal, M. (2002). Status of pesticide residues in brinjal (Solanum melongena L.): Indian Scenario. Annals of Agricultural Research, 23(3), 352-354 New Series.

Arora, S., \& Gopal, M. (2004). Residues of pendimethalin for weed control in cabbage crop (Brassica oleracea var L. Capitata). Bulletin of Environmental Contamination and Toxicology, 73, 106-110.

Arora, S., \& Singh, D. K. (2004). Residues of insecticides from IPM and non-IPM fields of okra and brinjal. Pesticide Research Journal, 16, 68-70.

Kole, R. K., Banerjee, H., \& Bhattacharyya, A. (2002). Monitoring of pesticide residues in farm gate vegetable samples in West Bengal. Pesticide Research Journal, 14, 77-82.

Madan, V. K., Kumari, B., Singh, R. V., Kumar, R., \& Kathpal, T. S. (1996). Monitoring of pesticide farm gate samples of vegetables in Haryana. Pesticide Research Journal, 8, 56-60.

Sardana, H. R., Arora, S., Singh, D. K., \& Kadu, L. N. (2004). Development and validation of adaptable IPM in eggplant, Solanum melongena L. in a farmer's participatory approach. Indian Journal of Plant Protection, 32, 123-128. 